\title{
Indonesian Agrarian Reform on Swapraja Land Meaning Assignment Based on Justice in Cirebon City
}

\author{
Pupu Sriwulan Sumaya \\ \{pupusumaya25@gmail.com\} \\ UniversitasNahdhotulUlama Cirebon, JalanSisingamangaraja No. 33, Lemahwungkuk, Panjunan, \\ Lemahwungkuk, Kota Cirebon, Jawa Barat 45111, Indonesia
}

\begin{abstract}
Legal reformation must be related to the history of the State, including swapraja as well as ex-swapraja. There is a disagreement of interpretations of swapraja or exswapraja between the Cirebon City Government and the Cirebon Kingdom. The government of Cirebon city considers the Kingdom of Cirebon as a part of swapraja land or ex-swapraja land. Each party defended its argument, which finally led to land conflict. Agrarian Law Dictum fourth (a) does not give a clear definition of what makes up a swapraja land, so make the other regulations. Assigning meaning to swapraja land must be done based on the historical perspective in terms of politics and legal about the existence of the swapraja land. The reformation of land law related to swapraja meaning must be made to achieve social justice, i.e., Pancasila social justice. The meaning assignment of swapraja must not be freed from the Cirebon city government in settling the dispute to create legal certainty in society. This research used socio legal method, started by building awareness on legal purpose to achieve justice, stability, and life prosperity. It is concluded that there must be proper law enforcement and just and certain law in society.
\end{abstract}

Keywords: Agrarian Reform, Swapraja Land, Legal Reformation, Cirebon City

\section{Introduction}

Swaprajaor ex-swapraja land's existence is part of legal policy in the land (an agrarian concept in strict meaning). Indonesia is in progress to be a nation state which experiences two leadership styles, namely Kingdom and Colonial Government. In progress of legal policy development, ex-colonial lands have been directly regulated by Agrarian Law. Kingdom land is known as swapraja land, yet dictum fourth (a) of Agrarian Law and Indonesian Government Regulation No. 224 the Year 1961 does not explain the indicators of swapraja and exswapraja land. The impact is that this regulation can be effectively implemented, including in Cirebon city. The meaning of swapraja or ex-swapraja land in the Indonesian Constitution has not yet to be adequately described. There is no clear definition in other regulations as well, for example in (1) Indonesian Constitution 1949, (2) Indonesian temporary constitution 1950, (3) Indonesian Constitution Before Amendment, and (4) Indonesian Constitution 1945 After Amendment. The government assigned the meaning of swapraja and ex-swapraja based on BoediHarsono's doctrine only. The minimum description of swapraja or ex-swapraja meaning makes various meaning and subjective perspectives from both parties, namely Government and Kingdom of Cirebon. Swapraja meaning has not found resultant between the Cirebon Kingdom and Cirebon City Government. 
Swapraja or ex-swapraja meaning cannot be leased from historical and culture of the kingdom in Indonesia. The Cirebon Kingdom has different histories with other kingdoms. Cirebon cannot be categorized as swapraja or ex-swapraja, because a swapraja or exswapraja must make an appointment with HindiaBelanda government (KorteVerklaring). The historical background of the Cirebon Kingdom from the past up until today shows that Cirebon is a wewengkon land (descendant land), not a swapraja or ex-swapraja land. The hegemony of state authority of the Cirebon City Government creates many implications, including conflicts. Such a condition needs land law restoration to clear up the meaning of swapraja based on justice.

\section{Methodology}

The study used a common-legal approach, in which is a legal study using the approach of law science and social sciences that leads to study to show and review the social and legal aspects of the application to a gap. The approach used is not dogmatic (normative), which means that the research used a non-doctrinal research methodology.

\section{Findings}

\subsection{Legal Restoration based on Pancasila}

Legal restoration is a part of legal policy that will or has been nationally executed by Indonesian Government which include: (1)legal restoration which mean making and restoration of legal material in order according to the need; and (2) implementation of legal rule, including affirmation of institution function of law officer[1]. Proper restoration is not new, and it is not for the past problem, as there is a protracted conflict because of the land problem. The land ruler has control over food and other utilities. Without understanding this meaning, people will be trapped in solving the agrarian problem partially, administration technically and legalistically; not sociologically, politically, and historically[2]

The legal policy explains about law and choices on a law that will be elapsed, which is entirely assigned to achieve state purpose as stated in Preamble of Constitution 1945. Hence, the national legal policy must be based on a basic frame, namely national legal policy; that must achieve a prosperous society based on Pancasila. The legal policy must protect the entire state for integrity or state unity, embodying social justice in economy and society to embody democracy (people sovereignty) and nomocracy (legal sovereignty) and to create tolerance based on civilization and humanity.

Pancasila, as a source of values for legal transformation as rechtsidee, according to Notonegoro, has a function as staatsfundamental norm. As a legal desire, it can fulfill a constitutive function and regulative function[3]. Through constitutive function, Pancasila determines based on legal regulation to assign meaning for the law itself. It is also related to the regulative function. Pancasila determines whether a positive law has been just or not. Justice cannot be elapsed from the root in which that law arises. Based on that explanation, BardaNawawiArief stated that justice could not be separated from religious law and living law, and it should be accommodated in national law. As philosofischiegroundslag, Pancasila philosophically can be a source of Indonesian legal order. In such position, Pancasila is a comprehensive source of every regulation in Indonesia.

Indonesia's law reformation in the meaning assignment of Swapraja based on Pancasila is aligned with Scholten'sstatetement that law science is science on justice[4]. It means that 
Indonesian legal science is science on Pancasila justice. Pancasila justice is Pancasila based on divine and humanistic justice, and it is a substantive justice, not a formalistic justice[5]. Swapraja and ex-swapraja meaning assignment in legal transformation need an indicator stipulation on the meaning of swapraja land. In other words, there must be an analysis of Cirebon's historical background, since the legal transformation is a never-ending process, and it must be based on Pancasila.

\subsection{Meaning assignment of Swapraja Based on Social Justice}

Gustav Radbruch taught that law must contain three fundamental values, namely: (1) the value of justice, (2) the value of certainty, and (3) the value of utility. The regulation is the implementation of those values and must not violate those values. Value in this context is mentioned as a justice value.

Different interpretation in swapraja or ex-swaprajameaning assignment in the Cirebon Kingdom's perspective is considered unjust. This is caused by different interpretations of swapraja and ex-swapraja meaning. It brings implications to the kingdom's land position. To minimize the conflict, there must be a reconstruction of swapraja and ex-swapraja meaning through resultant of related parties. It may result in a meaning reconstruction of swapraja based on Pancasila, which is social justice for all Indonesian that aims to bring prosperity for all. It means that everyone is treated justly without exemption.

Swapraja meaning is based on BoediHarsono's opinion that "swapraja is an area with its bureaucracy as part of Netherland Indische, the head is named Sultan, Sunan, King or etc based on agreement with Nederland Indische government to make its own bureaucracy (IndischeStaatsregeling 1855 Article 21 named; Zelfbestuur) in that area and its various culture[6]. Its agreement named as KorteVerklaring. It contains the oath to be loyal with Nederland government or its representative so that without korteverklaring, its area is not swapraja area but direct bureaucracy under Nederland government. There is no regulation with a clear definition of swapraja and in-swapraja, which requires efforts to create meaning of swapraja. Cirebon kingdom never agreed with the Nederland government, which is why the land is considered as nonswapraja area, and it had ceded its authority to England on July $20^{\text {th }}$, 1813.

Recently, Cirebon government has not admitted whether Cirebon kingdom land is a swaprajaorex-swapraja land. Justice must be brought into regulation. Social justice is not only the responsibility of Cirebon City Government but also the entire society. Social justice is stated in the fifth article of Pancasila: "Social justice for all Indonesian people." The problem arises, what is just in Pancasila conception.

The various interpretations need an understanding or resultant on land law transformation by reconstructing the insight on the meaning of swapraja through interaction between the people, City Government, and the Cirebon Kingdom. Through historical, political, and juridical background, there is a link between swapraja interpretations that depict social justice based on divinity, humanity, and unity, which are the results of discussions between the government and society.

\section{Conclusion}

Indonesia's law reformation in the meaning assignment of Swapraja based on Pancasila is aligned with Scholten'sstatetement that law science is science on justice. It means that Indonesian legal science is science on Pancasila justice. Pancasila justice is Pancasila based on 
divine and humanistic justice, and it is a substantive justice, not a formalistic justice. Meaning assignment on swapraja based on social justice is a result of compromises among the parties. To find a reciprocal relation between the Cirebon Kingdom and Cirebon City Government, compare the reality in society without putting aside historical background and local wisdom. A just Swapraja meaning must contain philosophical perspective, namely fulfillment of all rights in humanistic relation as an obligation. Humanistic relation has three dimensions, namely toward himself, God as the leading cause, and among human beings.

\section{References}

[1] N. K.; Y. S. L. Denzin, The Sage Handbook of Qualitative. Yogyakarta: Pustaka Pelajar, 2011.

[2] C. Hooker, "A New Problem - Solving Paradigm For Philosophy of Science," Perspect. Sci. J., vol. 26, no. 2, pp. 266-291, 2018.

[3] "Reliance of Suku Anak Dalam To Harapan Rainforest, Indonesia: FoodStuff Collection Preference," Int. J. Agric. Resour. Gov. Ecol., 2015.

[4] F. Rigaux, "Hans Kelsen on International Law,” Eur. J. Int. Law, p. 329, 1998.

[5] J. ; B. H. B. Frank, Law, And The Modern Mind. London: Routledge, 2017.

[6] D. Yu, "Customary Law in The Practice of Criminal Law: A Real and Powerful Role," Peking Univ. Law J., vol. 36, 2013. 